\title{
Pennsylvania-German Names of Trees
}

\author{
By C. D. Mell, Assistant Dendrologist, U. S. Forest Service
}

The study of the Pennsylvania-German names of trees is very interesting, especially since a number of these vernacular names are so different from those of the original high German that it is often difficult to recognize them as being derived from the latter. A great many of the original settlers of eastern Pennsylvania came from the country districts in southwestern Germany, bringing with them popular names for trees and other useful plants, which they gave to closely related forms found growing in America. Many of these names have survived till today. The word Kesten, which is a variant name for Kastania, the original high German word, being derived from the name of the territory of Castanea, in Thessaly, is an cxample of an introduced name. Grum Beeren, deriver from Grund Beeren, is a word in common use in southwestern Germany for Kartoffeln (potatoes), which, although not a tree, serves to illustrate the use of names in vogue in the fatherland. The English element that is scattered throughout the German speaking districts in Pennsylvania has also left its imprint upon plant names, as is shown in words like Shaelbark, the first part of which is distinctly German, meaning "to peel off," and the second name is English. Combinations of this kind are not infrequent.

Of course there are still a number of trees and shrubs growing in this part of the state for which no vernacular names exist, while a great many others are given a general term. The different oaks, for instance, are seldom distinguished beyond the two kinds, namely, the white (weiss Oeche) and black (swartz Oeche). The high German name for oak is Eiche of which Oeche is a corruption. The white oak, swamp white oak, post oak, and dwarf chinquapin oak are all classed under the general name weiss Oeche. Red oak, scarlet oak, yellow oak, pin oak, and black jack are all known as swartz Oeche. The most noted exceptions are the chestnut oak Quercus prinus Linn.), which is called kest Oeche, and red oak (Quercus rubra Linn.), which is sometimes called roth Oeche, but the latter is also used occasionally to designate the group of oaks above classed under swartz Oeche.

A short list of Pennsylvania-German names is given below:

\section{Penna.-German Name English Common Name}

Botanical Name

Oel Walnuss

Walnuss

Saeu Hickernuss

Weiser Hickernuss

Shaelbark

$$
\begin{gathered}
\text { Butternut } \\
\text { Black walnut } \\
\text { Pignut } \\
\text { Mockernut } \\
\text { Shellbark }
\end{gathered}
$$

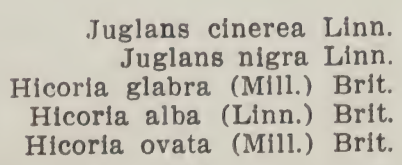

Juglans cinerea Linn. Juglans nigra Linn. Hicoria alba (Linn.) Brit. Hicoria ovata (Mill.) Brit.

The popular name of the shag bark is drawn from the striking appearance of its outer bark, which peels off in long narrow strips.

Weide

Trauer Weide

\section{Salicaceae}

Willow

Weeping willow
Salix nigra Marsh Salix babylonica Linn. 
Aside from the weeping willow, which is an introduced species, the Pennsylvania-Germans recognize only one kind. There are about eight or ten species native to eastern Pennsylvania, but they are not distinguished and are simply called Weide, or occasionally wasser Weide or Bruch-Weide. The latter is the high German name for crack willow, Salix fragilis Linn., and should not be used as a general term.

Bopple

Weiser Bopple

Aspen

Grosse Bopple
Salicacea (Continued)

Lombardy

European white poplar Quaking aspen

Large-toothed aspen

Betulaceae

Suess Birch
Populus nigra italica Du Rol. Populus alba Linn. Populus tremuloides Mich. Populus grandidentata Mich.

Betula lenta Linn.

The German and English names for this tree are so nearly alike that it did not take long for the Pennsylvania-German to drop the hard sound of $\mathrm{k}$ in the German name Birke in favor of the soft sound, $c h$ in the English name birch. The Teutonic name for this tree was Berka, whence it is easy to see how Birke and Birch came to be used later. The kind generally found along streams or in wet locations is called wasser Birch (Betula nigra Linn.) Othere species are seldom distinguished.

Airle

Buche

Kesten

Weiss Oeche

Swartz Oeche

Roth Oeche

Kest Oeche

Ulm
European alder

Fagaceae

Beech
Chestnut
White oak
Yellow oak
Red oak
Chestnut oak

\section{Ulmaceae}

American elm
Alnus glutinosa (Linu.) Gaertn. Castanea dentata (Marsh.) Borkh. Quercus alba Linn. Quercus velutina Lam. Quercus rubra Linn. Quercus prinus Linn.

Ulmus americana Linn.

The word Ulm is the high German name for the European elm (Ulmus campestris Linn.), and is now generally applied to the American elm (U1mus americana Linn.). Roosche is a name occasionally given to this tree in sections of Pennsylvania where the English speaking element has not yet replaced a great many of the German names formerly in use. It is derived from the middle high German Ruester. (not Ruestar), and is used as a general term for all species of elms.

Schluepfrige Al Slippery elm

Ulmus pubescens Walt.

The name $\mathrm{Al}$ is derived from European base meaning to grow or to nourish. The inner bark of this species has a very agreeable taste and aromatic odor when dry. Children frequently gather the bark and chew it, and it also has long played an important part in medicine, and among the Pennsylvania German people at the present day old apothecaries still attribute to it its ancient repute.

Weise Maul Beeren Swartze Maul Beeren

Hedge Baum or

Wilde orange Baum

Tulpen or Popple

Sassafras

\section{Moraceae}

White mulberry

Red mulberry

Osage orange

Magnolioceae

Yellow poplar

\section{Lauraceae}

Morus rubra Linn. Toxylon pomiferum Raf.

Morus alba Linn.

Liriodendron tulipfera LInn.

On account of th German settlers to possess a great many tree it was supposed by the early 
women employed the berries of sassafras trees against pain by washing the aching parts with a solution obtained bv boiling the berries in water. The bark of this tree was formerly used by the women in dying worsted a fine lasting orange color which is said not to have faded in the sun. The early settlers also gathered the flowers which were carefully dried in the shade to serve as a substitute for tea.

Suess Gumme

Wasser Beech

\section{Hamamelidaceae}

\section{Sweet gum}

Sycamore
Liquidambar styraciflua Linn. Platanus occidentalis Linn.

This tree has a very confusing list of Pennsylvania-German names. The wood of sycamore has a rather close resemblance to that of bech, and since the tree is generally found along streams it is often called wasser Beech. The German, however, corrupted the word to wasser Pitsch, and from this it was still further misnamed until today it is frequently called wasser Pitcher. The German ear is not very keen in detecting clearly certain aspirants. as for instance the $b$ and $p$ or $d$ and $t$, and it is therefore easy to see how the word became corrupted from beech to Pitch and later to Pitcher. The term wasser Pitcher, has a local usage and is not likely to find favor even among the most careless users of Pennsylvania-German plant names. It is also occasionally referred to as bolle Baum or knoep Baum, but these also are only local names.

Locus

Honig Locus
Locust

Leguminosae

Honey Locust

Aceraceae

Ahorn

Red maple

Robinia psendacacia Linn. Gleditsia triacanthos

Acer rubrum Linn.

The red maple is one of the most common native species of eastern Pennsylvania, ancl it is seldom that any other name cxcept maple is given to this tree. Occasionally one hears the word rother or feld Ahorn. The silver maple so generally cultivated is sometimes called spitz-blaettriger Ahorn.

\section{Hippocastanaceae}

Gaeuls Kesten

Horse chestnut

$$
\text { Linden }
$$

\section{Tiliaceae}

Linde

Hundsholz

Gumme Baum

Sparveln

\section{Cornaceae}

Dogwood

Black gum

\section{Ebenaceae}

\section{Persimmon}

Aesculus hippocastanum Linn.

Tilia americana Liun.

Cornus florida Linn. Nyssa sylvatica Marsh.

Diospyros virginiana Linn. The generic name of this tree is derived from dios, divine. and pyros, pear; resemblance of the fruit. The high German name for this tree is Dattelpflaume, a term which does not seem to have come into use in this country. Dattel is the German word for date, and pflaume for plum.

\section{Oleacae}

Aesche American ash

Fraxinus americana Linn

The popular high German name is usually written Esche, derived from the original Teutonic word Ask-oz. The Pennsylvania Germans have not as yet generally distinguished the several species of ashes native to eastern Pennsylvania, except that the ordinary white ash (Fraxinus americana Linn.) is occasionally referred to as weiser Aesche in order to distinguish it from the wasser Aesche, which is the black ash (Fraxinus nigra Marsh.), a species generally found in low swampy situations.

\section{Caprifoliaceae}


The common elcler (Sambucus racemosa Linn.) native to central and southern Europe is called Hohlunder in German. When the early German settlers came to America they found black elder, which they straightway called swartzer Hohlunder, which was soon corrupted to swartzer Huller.

Schaaf Beeren

Sheep berries

Viburnum lentago Linn. 